\title{
Adenosarcoma Pathologic TNM Finding v7
}

National Cancer Institute

\section{Source}

National Cancer Institute. Adenosarcoma Pathologic TNM Finding v7. NCI Thesaurus.

Code C89607.

A pathologic finding about one or more characteristics of adenosarcoma, following the rules of the TNM AJCC V7 classification system. 